\title{
CONSUMER'S PERCEPTION TOWARDS ONLINE SHOPPING- THE CASE OF PUNJAB
}

\author{
Kanwal Gurleen \\ Assistant Professor \\ Apeejay Institute of Management Technical Campus, Jalandhar
}

\begin{abstract}
India has more than 100 million internet users out of which one half opt for online purchases and the number is rising sharply every year. The growth in the number of online shoppers is greater than the growth in Internet users, indicating that more Internet users are becoming comfortable to shop online. The capability of purchasing without leaving your place is of great interest to many consumers. Not only does online shopping offer really good deals, but also brings optimum convenience to the consumers. Moreover, the use of Internet tools for price searching and comparison provides an additional advantage in consumers' final decision, as they can purchase their desired products in the lowest available price. This paper focuses on the understanding of demographic profiles of adopters and non-adopters of online shopping. For this purpose the data from 400 respondents was collected in the form of questionnaires. The study has been conducted in 3 cities of Punjab, a sample of urban respondents were selected from the Jalandhar, Ludhiana and Amritsar The paper also analyses the various reasons for adoption and non-adoption of online shopping.
\end{abstract}

KEYWORDS: Online Shopping, Consumer Perception, Factor analysis, Adopters and Non-Adopters of online shopping

\section{INTRODUCTION}

With nearly half of the Indian population being young and net savvy, there has been an extra ordinary rise in the numbers of online shoppers. The recent growth in the mall culture in the country has in fact made consumers more aware about different options and encouraged them to search and eventually purchase online. India has more than 100 million internet users out of which one half opt for online purchases and the number is rising sharply every year. The growth in the number of online shoppers is greater than the growth in Internet users, indicating that more Internet users are becoming comfortable to shop online. Until recently, the consumers generally visit online to reserve hotel rooms and buy air, rail or movie tickets, books and gadgets and gizmos, but now more and more offline product like clothes - saris, kurtis, T-shirts - shoes, and designer lingerie, consumer durables are being purchased online. At present the market is estimated at Rs. 46000 crore and is growing at 100 percent per year. The two most commonly cited reasons for online shopping have been convenience and price. The capability of purchasing without leaving your place is of great interest to many consumers. Not only does online shopping offer really good deals, but also brings optimum convenience to the consumers. Moreover, the use of Internet tools for price searching and comparison provides an additional advantage in consumers' final decision, as they can purchase their desired products in the lowest available price .On the contrary, privacy and security have been the great concerns, resulting many people to browse the Internet for informational matters than for buying online.

\section{REVIEW OF LITERATURE}

Bellman et al (1999) investigated various predictors for whether an individual will purchase online. These authors concluded that demographic variables, such as income, education and age, have a modest impact on the decision of whether to buy online, whereas the most important determinant of online shopping was previous behaviour, such as earlier online purchases. Standing (1999) stated that traditionally retail travel agencies have acted as intermediaries between airline companies and wholesale travel companies and the consumer. The Internet and the World Wide Web provide a whole new set of challenges and opportunities for this business sector. The major threat stems from airlines and wholesale travel companies offering their products and services directly to the customer without the assistance of travel agencies. Large online agencies have gained significant attention in the travel industry and provide some evidence of a restructuring of the travel industry sector. Leong (2001) examined the marketing strategies adopted by local hotel establishments in the competitive hospitality industry. It also analyses the adoption and role of information technology in strategic marketing. It was found that most hotels seemed to have embraced the marketing concept, given the existence of extensive marketing plans. Although most hotels appeared to have successfully incorporated information technology into their marketing campaigns, the level of commitment seemed to be insignificant. Following a brief comparison with a similar US study, the paper concludes that there are only minor differences between US and Singapore hotels in terms of their marketing practices. Parasuraman (2002) stated that the motivations for this special issue and propose a conceptual framework pertaining to the issue's theme. Using this frameworks a backdrop, they then offer an overview of the remaining articles by segmenting them into categories and discussing their relationship to the framework. They conclude by highlighting research avenues for augmenting our understanding of marketing to and serving customers through the Internet. Sigala (2003) stated that despite the exponential growth of e-commerce on the Internet, little is still known on how the new medium is transforming marketing concepts/practices and their effectiveness. This empirical study aims to fill in this gap. This article first analyzes the Internet's capabilities and features as well as the new virtual market space that Internet advances have fostered. After reviewing models and strategies for Internet marketing, an Internet marketing mix is proposed based on the Internet strategies of hotels in Greece that were investigated. Know and Lee (2003) explored consumers' concerns about payment security and its relationship to online shopping attitude and actual purchases. They observed a negative relationship between attitude towards online shopping and concerns about online payment security. Consumers with a positive attitude seem to be less concerned about payment security. Bechrer (2004) stated that Internet marketing is a field that is continuing to grow, and the online auction concept may be defining a totally new and unique distribution alternative. Very few studies have examined auction sellers and their 
internet marketing strategies. This research examines the internet auction phenomenon as it relates to the marketing mix of online auction sellers. The data in this study indicate that, whilst there is great diversity among businesses that utilize online auctions, distinct cost leadership and differentiation marketing strategies are both evident. These two approaches are further distinguished in terms of the internet usage strategies employed by each group. Ryan (2004) conducted a research on the mosaic of institutional issues associated with gaining credibility for internet marketing standards. Strong claims for a predominantly self-regulatory approach are reviewed in conjunction with other factors that inhibit credibility, namely: competing internet worldviews, weak moral coherency and offline ambiguity about respective institutional roles, especially as regards moral dimensions of notions of regulation and self-regulation. Wang (2006) conducted a research to examine the current use and predict future Web-based marketing activities of U.S. convention and visitor bureaus. A survey was sent to 600 randomly selected American convention and visitor bureaus with a focus on assessing the applications included in the bureaus' Web sites, their Web site promotion techniques, and customer relationship management programs in relation to these Web sites. The results indicate that most bureaus' Internet marketing activities are relatively limited, focusing on providing travel information to prospective visitors. Bengtsson (2007) stated that adopting the Internet for advanced marketing operations opens up challenging opportunities for firms of all sizes. However, such adoption might destroy investments in present market channels and thus has the characteristics of radical innovation. The results of analysis show that composition of factors on which firms base their decision to adopt advanced Internet-based marketing operations varies significantly with firm size. Chin ting (2010) stated that few school or educational studies have simultaneously explored both internet marketing and organizational commitment, and of those that have, only direct effects were examined. This study clarifies the relationship between school organization's internet marketing and teachers' organizational commitment by examining the mediating role of teachers' job involvement and job satisfaction.

\section{RESEARCH OBJECTIVES}

The study has been conducted to identify the consumer's perception towards online shopping in Punjab. The specific objectives of the study are:

- $\quad$ To identify the demographic profile of adopters and non-adopters of online shopping in Punjab.

- To identify the various reasons for adoption and non-adoption of online shopping by the consumers of Punjab

\section{DATABASE AND METHODOLOGY}

The research is primarily descriptive in nature. The data was collected in the form of questionnaires. The study has been conducted in 3 cities of Punjab, a sample of urban respondents were selected from the Jalandhar, Ludhiana and Amritsar. The survey was carried out on 450 respondents. However, 31 Questionnaires were found to be incorrect or irrelevant, so a total of 50 questionnaires were deliberately rejected. Hence, the study sample was reduced to 400 respondents. The data was collected personally (and via emails) in the months of January 2012 to March 2012. The questionnaire was pretested in order to identify possible problems in terms of clarity and accuracy. Thus, several changes were made in order to improve the presentation of the items, based on comments and feedback. Apart from demographic-related questions, fivepoint Likert scale was used for all the questions concerning consumers' expectations and perceptions about the online shopping. Most of the Respondents of the age group 36-45 years $(44.6 \%)$ were found to be adopters of online shopping (Table 1). Most of the Males (55.3\%) were the adopters as compared to females, where $53.7 \%$ were non-adopters. The adopters were mostly post graduates $(48.9 \%)$ with monthly income in the range of Rs.20000-Rs.30000. The respondents those who use internet from 5 to 7 hours a day were found to be adopters of online shopping. The consumer responses ranked the retail websites at Number 1 with Electronics and comparison shopping websites at Number 2 and 3 respectively. Home items were ranked at Number 10 by the Punjab consumers (Table 2)

Table 1 : Demographic profile of Adopters and Non Adopters

\begin{tabular}{|c|c|c|c|c|c|}
\hline \multirow[t]{2}{*}{ Demographics } & \multicolumn{2}{|c|}{ Adopters } & \multicolumn{2}{|c|}{ Non Adopters } & \multirow[t]{2}{*}{ Chi - square } \\
\hline & & $\%$ & & $\%$ & \\
\hline Age: & & & & & \\
\hline $15-25$ & 34 & $18.0 \%$ & 45 & $21.2 \%$ & $\mathrm{df}=3$ \\
\hline $26-35$ & 67 & $35.6 \%$ & 72 & $33.9 \%$ & chi-square $=48.241$ \\
\hline $36-45$ & 84 & $44.6 \%$ & 91 & $42.9 \%$ & $\mathrm{p}=0.000$ \\
\hline Above 46 & 03 & $1.5 \%$ & 04 & $1.8 \%$ & \\
\hline Gender: & & & & & \\
\hline Female & 84 & $44.6 \%$ & 114 & $53.7 \%$ & $\mathrm{df}=1$ \\
\hline Male & 104 & $55.3 \%$ & 98 & $46.2 \%$ & $\begin{array}{l}\text { chi-square }=53.892 \\
\mathrm{p}=0.000\end{array}$ \\
\hline
\end{tabular}




\begin{tabular}{|l|l|l|l|l|l|}
\hline Education: & 31 & $16.4 \%$ & 56 & $26.4 \%$ & $\mathrm{df}=3$ \\
Under Graduate & 43 & $22.8 \%$ & 62 & $29.2 \%$ & chi-square=72.452 \\
Praduate & 92 & $48.9 \%$ & 86 & $40.5 \%$ & $\mathrm{p}=0.000$ \\
Any Other & 20 & $10.6 \%$ & 08 & $3.7 \%$ & \\
\hline Monthly Income: & 18 & $9.5 \%$ & 42 & $19.8 \%$ & $\mathrm{df}=4$ \\
Under Rs.10000 & 37 & $19.6 \%$ & 51 & $24.0 \%$ & chi-square=67.453 \\
Rs.10000-Rs.20000 & 78 & $41.4 \%$ & 69 & $32.5 \%$ & $\mathrm{p}=0.000$ \\
Rs.20000-Rs.30000 & 55 & $29.2 \%$ & 45 & $21.2 \%$ & \\
More than Rs.30000 & 00 & $0.0 \%$ & 05 & $2.3 \%$ & \\
Not Employed & 21 & $11.1 \%$ & 47 & $22.1 \%$ & $\mathrm{df}=4$ \\
\hline Daily usage of the Internet & 38 & $20.2 \%$ & 53 & $25.0 \%$ & chi-square=77.344 \\
1 hour and below & 56 & $29.7 \%$ & 71 & $33.4 \%$ & $\mathrm{p}=0.000$ \\
$1-3$ hours & 65 & $34.5 \%$ & 39 & $18.3 \%$ & \\
$3.1-5$ hours & 08 & $4.2 \%$ & 02 & $0.94 \%$ & \\
$5.1-7$ hours & & & & & \\
7 hours and above & & & & \\
\hline
\end{tabular}

Table 2: Most visited category of websites:

\begin{tabular}{|l|c|c|}
\hline Category of Websites & Rank & Mean \\
\hline Retail & 1 & 3.45 \\
\hline Consumer Electronics & 2 & 3.12 \\
\hline Comparison Shopping & 3 & 2.98 \\
\hline Computer Hardware & 4 & 2.87 \\
\hline Apparel & 5 & 2.64 \\
\hline Movies & 6 & 2.55 \\
\hline Books & 7 & 2.03 \\
\hline Flowers/Gifts/Greetings & 8 & 1.76 \\
\hline Jewelry/Luxury Goods/Accessories & 9 & 1.46 \\
\hline Home items & 10 & 1.55 \\
\hline
\end{tabular}

\section{Reasons for adoption or non-adoption of online shopping}

The factor analysis was applied on the responses provided by respondents. Factor analysis is a good way of identifying latent or underlying factors from an array of seemingly important variables. In a more general way, factor analysis is a set of techniques, which, by analyzing correlations between variables, reduces their number into fewer factors, which explain much of the original data, more economically.(Malhotra,2002). In the present study, the factor analysis was applied in order to identify the various reasons for online shopping by the consumers, the responses obtain were put to factor analysis and the result so obtain were subject to Kaiser- Meyer- Olkin (KMO) measure of sampling adequacy and Bartlett's Test of Sphericity. The approximate chi-square value is 621.103 with df 290 , which is significant at 0.000 level.(Table 3). The value of KMO statistics $(0.783)$ is also large $(>0.5)$. Hence, all factors are not considered equally important for Television viewing.

From table 4, it is evident that the first four variables represent the $62.092 \%$ of variance. Therefore, only these four factors with the variance greater than 1.0 are retained and the other factors are not included in the model. Thus, from eigen values in table 3 , we extract only 4 factors from the 13 variables.

\section{Table 3 : KMO and Bartlett's test}




\begin{tabular}{|l|l|c|}
\hline Kaiser-Meyer-Olkin Measure of Sampling Adequacy. & & .783 \\
\hline Bartlett's Test of Sphericity & Approx. Chi-Square & 621.103 \\
\hline & Degree of Freedom & 290 \\
\hline & Significance & .000 \\
\hline
\end{tabular}

Table 4: Total Variance explained

\begin{tabular}{|c|c|c|c|c|c|c|c|c|c|}
\hline & \multicolumn{3}{|c|}{ Initial Eigenvalues } & \multicolumn{3}{|c|}{ Extraction Sums of Squared Loadings } & \multicolumn{2}{|c|}{$\begin{array}{c}\text { Rotation Sums of Squared } \\
\text { Loadings }\end{array}$} & \multirow[b]{2}{*}{$\begin{array}{c}\text { Cumulative } \\
\%\end{array}$} \\
\hline Component & Total & $\begin{array}{c}\% \text { of } \\
\text { Variance }\end{array}$ & $\begin{array}{c}\text { Cumulative } \\
\%\end{array}$ & Total & $\begin{array}{c}\% \text { of } \\
\text { Variance }\end{array}$ & $\begin{array}{c}\text { Cumulative } \\
\%\end{array}$ & Total & $\begin{array}{c}\% \text { of } \\
\text { Variance }\end{array}$ & \\
\hline 1 & 4.150 & 27.823 & 27.823 & 4.150 & 27.823 & 27.823 & 3.921 & 27.823 & 27.823 \\
\hline 2 & 3.144 & 14.230 & 42.053 & 3.144 & 14.230 & 42.053 & 3.101 & 14.230 & 42.053 \\
\hline 3 & 2.718 & 10.783 & 52.836 & 2.718 & 10.783 & 52.836 & 2.318 & 10.783 & 52.836 \\
\hline 4 & 1.411 & 9.256 & 62.092 & 1.411 & 9.256 & 62.092 & 1.290 & 9.256 & 62.092 \\
\hline 5 & 0.892 & 6.068 & 68.160 & & & & & & \\
\hline 6 & 0.789 & 5.130 & 73.290 & & & & & & \\
\hline 7 & 0.618 & 5.003 & 78.293 & & & & & & \\
\hline 8 & 0.601 & 4.781 & 83.074 & & & & & & \\
\hline 9 & 0.590 & 4.350 & 87.424 & & & & & & \\
\hline 10 & 0.449 & 4.263 & 91.687 & & & & & & \\
\hline 11 & 0.332 & 2.963 & 94.650 & & & & & & \\
\hline 12 & 0.217 & 2.788 & 97.438 & & & & & & \\
\hline 13 & 0.189 & 2.562 & 100.00 & & & & & & \\
\hline
\end{tabular}

\section{Extraction Method: Principal Component Analysis}

Factor loadings are simple correlations between the variables and factors. The most commonly used method is the Varimax

Table 5:Rotated Component Matrix rotation procedure. This is an orthogonal method of rotation that minimizes the number of variables with high loadings of a factor, thereby enhancing the interpretability of the factors. Orthogonal rotations results in factors that are uncorrelated.

\begin{tabular}{|c|c|c|c|c|c|}
\hline & & \multicolumn{4}{|c|}{ Component } \\
\hline S.No. & Statements & 1 & 2 & 3 & 4 \\
\hline 1 & I prefer to purchase online due to heavy discounts available online & .609 & .427 & .379 & .235 \\
\hline 2 & It is easier to buy online rather than going on to shop at store & .361 & .521 & .389 & .260 \\
\hline 3 & Shopping online gives you larger options to choose from & .212 & .517 & .412 & .352 \\
\hline 4 & It is easier to pay online through credit card or direct bank transfer & .341 & .489 & .656 & .419 \\
\hline 5 & $\begin{array}{l}\text { The quality of products purchased online from trusted sites is very good and } \\
\text { are available at economical prices }\end{array}$ & .425 & .336 & .316 & .296 \\
\hline 6 & $\begin{array}{l}\text { Shopping online saves my time and money as I don't have to go through heavy } \\
\text { traffic besides saving fuel }\end{array}$ & .380 & .552 & .272 & .461 \\
\hline
\end{tabular}




\begin{tabular}{|c|c|c|c|c|c|}
\hline 7 & I am a bit concerned about the security and privacy of my payments online & .402 & .326 & .561 & .613 \\
\hline 8 & I cannot buy all the products on discount but some selected products only & .642 & .561 & .452 & .497 \\
\hline 9 & There are some shipping delays in getting the product & .285 & .223 & .311 & .591 \\
\hline 10 & I do not use the credit card so I cannot often shop online & .403 & .326 & .262 & .570 \\
\hline 11 & I prefer to purchase online due to easement of online buying procedures & .502 & .346 & .663 & .371 \\
\hline 12 & I physically need to check the products before purchasing it & .325 & .436 & .516 & .696 \\
\hline 13 & $\begin{array}{l}\text { I can read the reviews also before purchasing online which helps me to select } \\
\text { the right product at economical prices }\end{array}$ & .580 & .352 & .431 & .280 \\
\hline
\end{tabular}

Principal Component Analysis under the rotation method (Varimax with Kaiser Normalization), rotation converged in 15 iterations. The following four components (Table 6) may be extracted:

Component 1: Factor 1,5,8,13 (Price Consciousness)

Component 2:Factor 2,3,6 (Convenience and Variety)
Component 3:Factor 4,11 (Easy payment options)

Component 4:Factor 7,9,10,12 (Challenges of online shopping)

The rotated component matrix suggests presence of the four interrelated factors.

Table 6: Naming of Factors

\begin{tabular}{|c|c|c|c|c|}
\hline $\begin{array}{l}\text { Factor } \\
\text { No. }\end{array}$ & $\begin{array}{l}\text { Name of } \\
\text { Dimension }\end{array}$ & $\begin{array}{l}\text { Item } \\
\text { No. }\end{array}$ & Variables & $\begin{array}{l}\text { Factor } \\
\text { loading }\end{array}$ \\
\hline \multirow[t]{4}{*}{ F1 } & \multirow[t]{4}{*}{$\begin{array}{l}\text { Price } \\
\text { Consciousness }\end{array}$} & 1 & I prefer to purchase online due to heavy discounts available online & .609 \\
\hline & & 5 & $\begin{array}{l}\text { The quality of products purchased online from trusted sites is very } \\
\text { good and are available at economical prices }\end{array}$ & .425 \\
\hline & & 8 & $\begin{array}{l}\text { I cannot buy all the products on discount but some selected products } \\
\text { only. }\end{array}$ & .642 \\
\hline & & 13 & $\begin{array}{l}\text { I can read the reviews also before purchasing online which helps me } \\
\text { to select the right product at economical prices }\end{array}$ & .580 \\
\hline \multirow[t]{3}{*}{$\mathbf{F 2}$} & \multirow{3}{*}{$\begin{array}{l}\text { Convenience and } \\
\text { Variety }\end{array}$} & 2 & It is easier to buy online rather than going on to shop at store & .521 \\
\hline & & 3 & Shopping online gives you larger options to choose from & .517 \\
\hline & & 6 & $\begin{array}{l}\text { Shopping online saves my time and money as I don't have to go } \\
\text { through heavy traffic besides saving fuel }\end{array}$ & .552 \\
\hline \multirow[t]{2}{*}{ F3 } & \multirow[t]{2}{*}{$\begin{array}{l}\text { Easy payment } \\
\text { options }\end{array}$} & 4 & It is easier to pay online through credit card or direct bank transfer & .656 \\
\hline & & 11 & $\begin{array}{l}\text { I prefer to purchase online due to easement of online buying } \\
\text { procedures. }\end{array}$ & .663 \\
\hline \multirow[t]{4}{*}{$\mathbf{F 4}$} & \multirow[t]{4}{*}{$\begin{array}{l}\text { Challenges of online } \\
\text { shopping }\end{array}$} & 7 & $\begin{array}{l}\text { I am a bit concerned about the security and privacy of my payments } \\
\text { online }\end{array}$ & .613 \\
\hline & & 9 & There are some shipping delays in getting the product. & .591 \\
\hline & & 10 & I do not use the credit card so I cannot often shop online & .570 \\
\hline & & 12 & I physically need to check the products before purchasing it & .696 \\
\hline
\end{tabular}

Price Consciousness: It is the most significant factor with 27.823 percent of total variance explained. This explains the intent of Punjab Consumers being price sensitive. Most of the consumers prefer to buy some selected products online because they will get heavy discounts in comparison to store purchases. Also, the consumers feels that there are good websites available which can be trusted for purchases. 
Convenience and Variety: It is the second most significant factor with 14.230 percent of total variance explained. The consumers perceive that shopping online gives them larger options to choose from. Shopping online is very convenient as one has to just open a laptop or PC to shop rather then getting ready and pass through rush hour traffics.

Easy Payment options: It is the third most significant factor with 10.783 percent of total variance explained. Consumers feel that carrying cash or credit cards all the way to the store is meaning less if one can purchase the same product from their home.

Challenges of Online Shopping: It is the fourth most significant factor with 9.256 percent of total variance explained. The only worry of consumers is regarding the trustworthiness of some websites, since they have to give their credit card details to shop online.

\section{CONCLUSIONS}

It was seen from the study that most of the Respondents of the age group 36-45 years were found to be adopters of online shopping. Most of the Males were the adopters as compared to females, where $53.7 \%$ were non-adopters. The adopters were mostly post graduates with monthly income in the range of Rs.20000-Rs.30000. The respondents those who use internet from 5 to 7 hours a day were found to be adopters of online shopping. Further, the factor analysis was applied to understand the various reasons for adoption and non-adoption of online shopping by the respondents. The following four factors were found to be significant Price Consciousness, Convenience and Variety, Easy Payment options and Challenges of Online Shopping. Most of the consumers prefer to buy some selected products online because they will get heavy discounts in comparison to store purchases. Also, the consumers feels that there are good websites available which can be trusted for purchases. The consumers perceive that shopping online gives them larger options to choose from. Shopping online is very convenient as one has to just open a laptop or PC to shop rather then getting ready and pass through rush hour traffics. Shopping online saves time and money along with lesser effort is required in comparison to store purchases.Consumers feel that carrying cash or credit cards all the way to the store is meaning less if one can purchase the same product from their home. The educated consumers are aware of the buying procedures online which they feel are pretty simple. The only worry of consumers is regarding the trustworthiness of some websites, since they have to give their credit card details to shop online. Many of the consumers are aware of the various online scams due to which they are very concerned and reluctant while providing their credit card information online. Also the online purchases take a longer time in shipments and deliveries. The psychology of an Indian consumer is still the same of checking the product physically before purchasing it, which creates a mental hurdle for online shopping.

\section{REFERENCES}

- Bechrer C. (2004). Characteristics and internet marketing strategies of online auction sellers. International Journal of Internet Marketing and Advertising. 24(1), 24-37

- Bellman, S., Lohse, G. and Johnson, E. (1999) 'Predictors of online buying behaviour,' Communications of the ACM, 42 (12), 32-38.

- Bengtsson M. (2007). Integrating the Internet and Marketing Operations: A Study of Antecedents in Firms of Different Size. International Small Business Journal. 25(1), 27-48

- Chin ting S. (2010). The Effect of Internal Marketing on Organizational Commitment: Job Involvement and Job Satisfaction as Mediators. Educational Administration Quarterly. 39(4), 65-74

- Know, K. and Lee, J. (2003) 'Concerns about payment security of Internet purchases: a perspective on current on-line shoppers,' Clothing and Textiles Research Journal, 21 (4), 174-184.

- Leong C. (2001). Marketing practices and Internet marketing: A study of hotels in Singapore. Journal of Vacation Marketing. 7(2), 179-187

- Parsuraman A. (2002). Marketing to and Serving Customers through the Internet: An Overview and Research Agenda. Journal of the Academy of Marketing Science. 30(4), 96-105

- Ryan P. (2004). Internet marketing standards: institutional coherence issues. International Journal of Internet Marketing and Advertising. 15(4), 84103

- Schiffman L. (2007) Consumer Behavior, New Delhi: Prentice Hall India

- Sigalla M. (2003). Developing and Benchmarking Internet Marketing Strategies in the Hotel Sector in Greece. Journal of Hospitality \& Tourism Research. 27(4), 375-401

- Standing C. (1999). Internet marketing strategies used by travel agencies in Australia. Journal of Vacation Marketing. 6(1), 36-42

- Wang Y. (2006). Futuring Internet Marketing Activities Using Change Propensity Analysis. Journal of Travel Research. 45(2), 158-166 